

\section{Net-Zero Energy Buildings: A Classification System Based on Renewable Energy Supply Options}

Technical Report NREL/TP-550-44586 June 2010

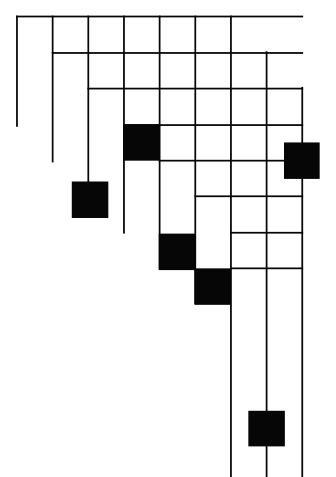

Shanti Pless and Paul Torcellini

Prepared under Task Nos. BEC7.1210, BEC7.1123

National Renewable Energy Laboratory 1617 Cole Boulevard, Golden, Colorado 80401-3393 303-275-3000 • www.nrel.gov

NREL is a national laboratory of the U.S. Department of Energy Office of Energy Efficiency and Renewable Energy

Operated by the Alliance for Sustainable Energy, LLC

Contract No. DE-AC36-08-GO28308 


\section{NOTICE}

This report was prepared as an account of work sponsored by an agency of the United States government. Neither the United States government nor any agency thereof, nor any of their employees, makes any warranty, express or implied, or assumes any legal liability or responsibility for the accuracy, completeness, or usefulness of any information, apparatus, product, or process disclosed, or represents that its use would not infringe privately owned rights. Reference herein to any specific commercial product, process, or service by trade name, trademark, manufacturer, or otherwise does not necessarily constitute or imply its endorsement, recommendation, or favoring by the United States government or any agency thereof. The views and opinions of authors expressed herein do not necessarily state or reflect those of the United States government or any agency thereof.

Available electronically at http://www.osti.gov/bridge

Available for a processing fee to U.S. Department of Energy and its contractors, in paper, from:

U.S. Department of Energy

Office of Scientific and Technical Information

P.O. Box 62

Oak Ridge, TN 37831-0062

phone: 865.576 .8401

fax: 865.576 .5728

email: mailto:reports@adonis.osti.gov

Available for sale to the public, in paper, from:

U.S. Department of Commerce

National Technical Information Service

5285 Port Royal Road

Springfield, VA 22161

phone: 800.553 .6847

fax: 703.605.6900

email: orders@ntis.fedworld.gov

online ordering: http://www.ntis.gov/ordering.htm 


\section{Executive Summary}

A net-zero energy building (NZEB) is a residential or commercial building with greatly reduced energy needs. In such a building, efficiency gains have been made such that the balance of energy needs can be supplied with renewable energy technologies. Past work has developed a common NZEB definition system, consisting of four well-documented definitions, to improve the understanding of what net-zero energy means. For this paper, we created a classification system for NZEBs based on the renewable sources a building uses. A building that offsets all its energy use from renewable resources that are available within the footprint is at the top of the NZEB classification system at an NZEB:A. A building that achieves an NZEB definition through a combination of on-site renenewables and off-site purchases of renewable energy credits is placed at the lowest end of the NZEB classification at an NZEB:D. We also look at how this classification relates to the previously developed NZEB definitions. The goal of this type of classification is to encourage NZEB owners and NZEB designers to first use all possible cost-effective energy efficiency strategies, and then use renewable sources and technologies that are located on the building and at the site. We have provided for lower classes of NZEB to include buildings whose energy use exceeds the renewable energy available at the site. This NZEB classification system is applicable to both single building projects as well as a set of buildings in a community or campus. 


\section{Acronyms and Abbreviations}

NZEB net-zero energy building

NZEB:A A footprint renewables NZEB

NZEB:B A site renewables NZEB

NZEB:C An imported renewables NZEB

NZEB:D An off-site purchased renewables NZEB

PV photovoltaic

RE renewable energy

REC renewable energy credit 


\section{Contents}

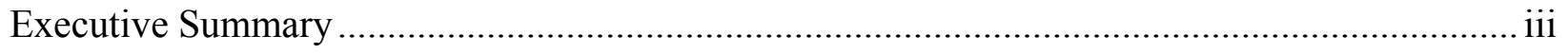

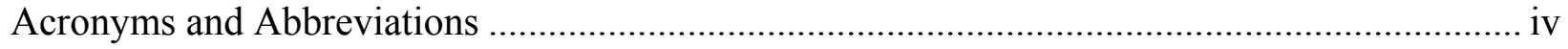

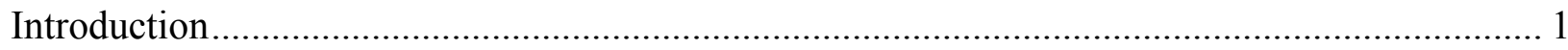

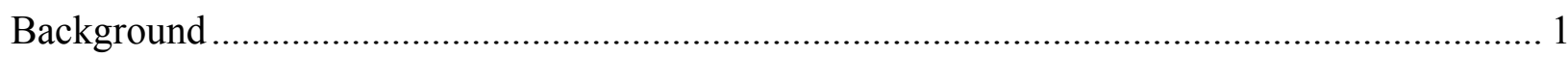

Net-Zero Energy Building Concepts and Assumptions ......................................................... 2

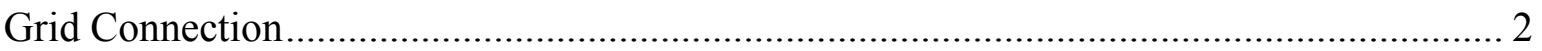

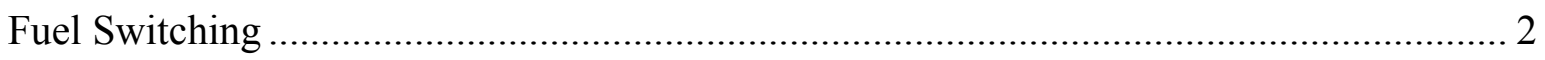

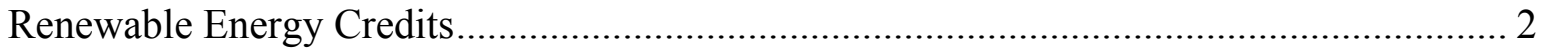

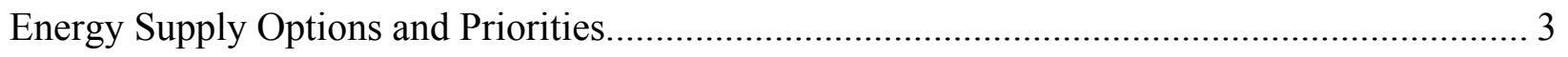

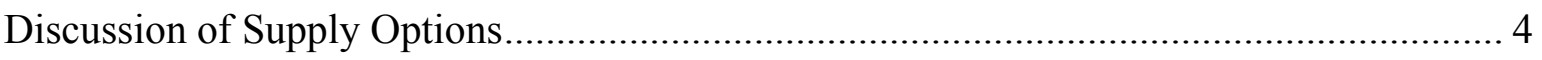

Option 0 - Low-Energy Buildings............................................................................. 4

Option 1 - Renewable Energy Generated Within the Building Footprint......................... 5

Option 2 - Renewable Energy Generated Within the Boundary of the Building Site ...... 5

Option 3 - Off-Site Renewable Energy Used To Generate Energy On Site ...................... 5

Option 4 - Purchase Renewable Energy Generated Off Site ………………………........ 7

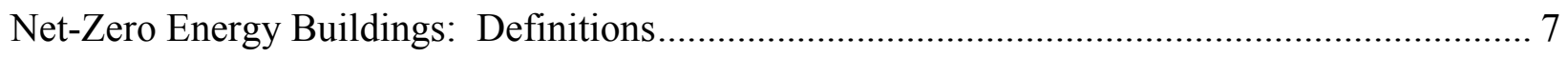

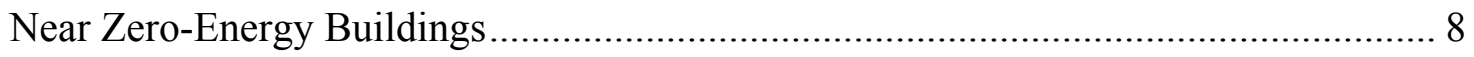

Applying a Classification System to Net-Zero Energy Buildings .............................................. 8

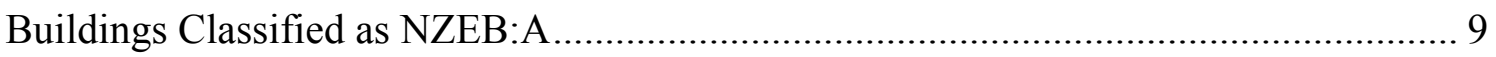

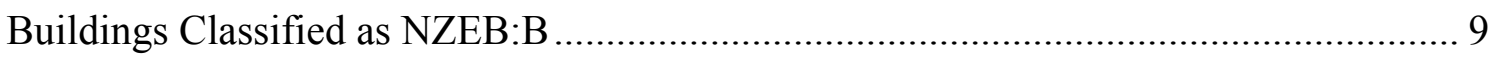

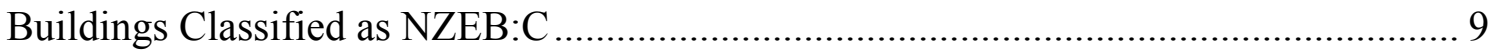

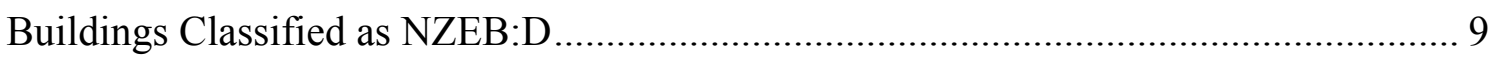

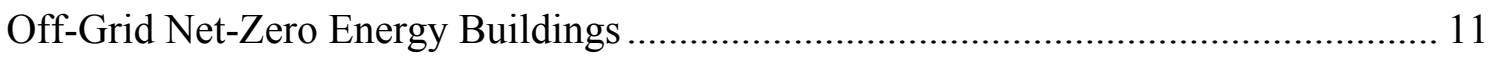

Zero Energy Beyond a Single Building ..................................................................... 11

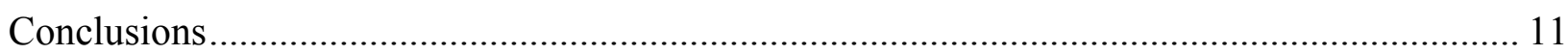

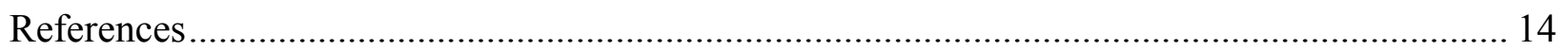

\section{Tables}

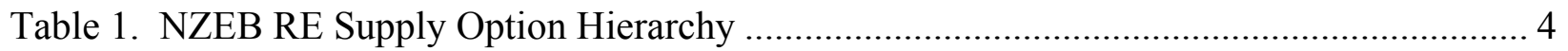

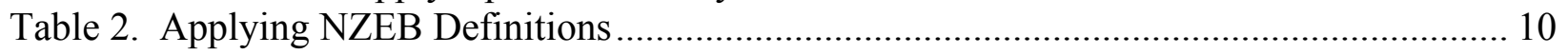

\section{Figure}

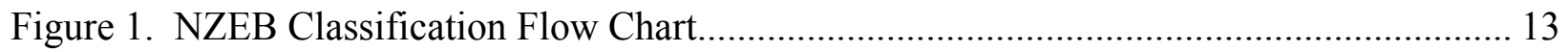




\section{Introduction}

Buildings have a significant impact on energy use and the environment. Commercial and residential buildings use almost $40 \%$ of the primary energy and approximately $70 \%$ of the electricity in the United States (EIA 2005). The energy used by the building sector continues to increase, primarily because new buildings are constructed faster than old ones are retired. Electricity consumption in the commercial building sector doubled between 1980 and 2000, and is expected to increase another $50 \%$ by 2025 (EIA 2005). Energy consumption in the commercial building sector will continue to increase until buildings can be designed to use energy efficiently and produce enough energy to offset the growing energy demand of these buildings. Toward this end, the U.S. Department of Energy has established an aggressive goal to create the technology and knowledge base for cost-effective net-zero energy commercial buildings (NZEBs) by 2025.

\section{Background}

In concept, an NZEB is a building with greatly reduced operational energy needs. In such a building, efficiency gains have been made such that the balance of the energy needs can be offset by renewable technologies. Torcellini et al. (2006) developed an NZEB definition system to improve the understanding of what zero energy means. They developed four documented definitions - net-zero site energy, net-zero source energy, net-zero energy costs, and net-zero energy emissions. Each NZEB definition, corresponding to a different energy use accounting method, has merits as a zero energy design goal; however, there is no single best accounting method. The NZEB definition used should align with the owner's goals for the project. This paper adds another dimension to the NZEB definitions based on a hierarchy of possible renewable energy (RE) supply options for NZEBs.

We propose a classification grading system for NZEBs based on the RE sources a building uses. NZEB classifications from NZEB:A to NZEB:D are proposed based on the RE type and location with respect to a building. This classification system recognizes that there are many possible RE supply options, depending on the site constraints and locally available renewable options. We also look at how this classification applies to the previously developed NZEB accounting methods. This technical report further documents and details this classification system that was originally summarized by Crawley et al. (2009).

Using NZEB design goals takes us out of designing low-energy buildings with a percent energy savings goal and into the realm of a more sustainable energy end point. The goals that are set and how those goals are defined are critical to the design process. The definitions will influence designers who strive to meet the goals (Deru and Torcellini 2004). Because design goals are so important to achieving high-performance buildings, the way an NZEB goal is defined is crucial to understanding the combination of applicable efficiency measures and RE supply options. This NZEB accounting and classification system is applicable to owners developing design goals, to architects and engineers tracking the modeled performance of the design, and to operators measuring the energy use. The NZEB status should be measured, reviewed, and tracked each year. 


\section{Net-Zero Energy Building Concepts and Assumptions}

\section{Grid Connection}

Before discussing the RE supply options available to NZEBs, we must look at the issue of grid connection. Conceptually, an NZEB produces as much as or more energy than it uses annually and exports excess RE generation to the utility (electricity grid, district hot water system, or other central energy distribution system) to offset the energy used. For NZEBs, a utility connection is allowed for energy balances. A grid-connected NZEB uses traditional energy sources such as electricity and natural gas utilities when on-site generation from RE does not meet the loads. When the on-site generation exceeds the building's loads, excess energy is exported to the utility. By using the utility to account for the energy balance, excess production can offset later energy use.

We assume that excess on-site generation can always be sent to the grid to be fully used. However, in high market penetration scenarios, the grid may not always need this energy. In this scenario (and depending on the electricity utility), on-site energy storage would become necessary to maintain the zero energy status of the building.

Off-grid NZEBs are also possible under this classification system; however, they typically require additional on-site generation capabilities combined with significant energy storage technologies. Backup energy sources for off-grid NZEBs would also have to be supplied with $\mathrm{RE}$ fuels under this classification system.

\section{Fuel Switching}

The NZEB definitions and classifications enable renewable electricity generation to offset various fossil fuel energy uses. For example, natural gas energy use can be offset with excess photovoltaic $(\mathrm{PV})$ or wind energy exported to the grid; the offset level is determined by the energy use accounting method. A site energy accounting allows for a 1-to-1 offset between fuels; source energy can place an additional offset (approximately 3-to-1) for renewable electricity exported to the grid. These source-to-site ratios are well documented and vary depending on the utility mix (Deru et al. 2007).

\section{Renewable Energy Credits}

Many RE projects are partially financed through the sales of renewable energy credits (RECs). Although this is an important financial tool, once the RECs are sold and then purchased by someone else, the project cannot claim the benefits of the RE produced on site for the purposes of our NZEB classification. In some utility purchase models, the RECs are not resold; rather, they are retired and used by the utility to meet a renewable portfolio standard obligation. In these examples - where a project does not own or retain its RECS - the project's RE is not available as an RE option in the NZEB context. This is to avoid double counting the RECs. If the project buys back an equivalent amount of certified RECs, such as Xcel's Windsource (Xcel 2010) or Green-E certified renewables (Green-E 2009), the project's on-site RE is available for credit toward an NZEB position for as long as the project purchases equivalent RECs. 


\section{Energy Supply Options and Priorities}

Various supply-side RE generation technologies are available for NZEBs (Torcellini et al. 2006). Typical examples of these technologies include PV, solar hot water connected to a district hot water system, wind, hydroelectricity, and biofuels. Demand-side RE and efficiency measures include strategies that save energy but typically are not commoditized. These cannot be included in the supply-side balance for achieving an NZEB. Typical examples of demand-side RE and energy efficiency strategies include passive solar heating, daylighting, solar ventilation air preheaters, and domestic solar water heaters.

Guiding principles for RE in NZEBs were developed to minimize the energy transfers from generation source to end use and provide long-term maintainability in the built environment:

- Minimize the overall environmental impact by encouraging energy-efficient building designs, using emissions-free RE, and reducing transportation, transmission, and conversion losses.

- Will be available over the lifetime of the building.

- Are highly scalable, widely available, and have high replication potential for future NZEBs.

We developed a hierarchy of RE sources in the NZEB context to reflect these principles. Table 1 shows this ranking in order of preferred application.

This hierarchy is weighted toward RE technologies that are available within the building footprint and at the site. Rooftop PV and solar water heating are the most applicable supply-side technologies for widespread application of NZEBs. Other supply-side technologies such as parking lot-based wind or PV systems may be available for limited applications. A good NZEB should first encourage energy efficiency, and then use RE sources that are available within the building footprint - the definitions and classification system support this. However, some high energy use building types such as hospitals and grocery stores cannot realistically apply efficiency measures to the point where they can offset all energy use with a combination of onbuilding and on-site renewables. Therefore, this NZEB classification system includes off-site supply options so all possible building types can potentially reach an NZEB position.

This hierarchy was initially discussed by Torcellini et al. (2006). We have since expanded to a formal classification system, added detail to the RE source hierarchy, and modified it to accommodate specific site details and energy uses. After examining several NZEBs and how people use the definitions, we added a discussion to address RE use for campus and neighborhood environments. Table 1 provides a brief overview of each energy supply option and is followed by a discussion of each. 
Table 1. NZEB RE Supply Option Hierarchy

\begin{tabular}{|c|c|c|}
\hline $\begin{array}{l}\text { Option } \\
\text { Number }\end{array}$ & NZEB Supply-Side Options & Examples \\
\hline 0 & $\begin{array}{l}\text { Reduce site energy use through energy } \\
\text { efficiency and demand-side renewable } \\
\text { building technologies. }\end{array}$ & $\begin{array}{l}\text { Daylighting; insulation; passive solar } \\
\text { heating; high-efficiency heating, } \\
\text { ventilation, and air-conditioning } \\
\text { equipment; natural ventilation, evaporative } \\
\text { cooling; ground-source heat pumps; } \\
\text { ocean water cooling }\end{array}$ \\
\hline \multicolumn{3}{|c|}{ On-Site Supply Options } \\
\hline 1 & $\begin{array}{l}\text { Use RE sources available within the } \\
\text { building footprint and connected to its } \\
\text { electricity or hot/chilled water distribution } \\
\text { system. }\end{array}$ & $\begin{array}{l}\text { PV, solar hot water, and wind located on } \\
\text { the building }\end{array}$ \\
\hline 2 & $\begin{array}{l}\text { Use RE sources available at the building } \\
\text { site and connected to its electricity or } \\
\text { hot/chilled water distribution system. }\end{array}$ & $\begin{array}{l}\text { PV, solar hot water, low-impact hydro, and } \\
\text { wind located on parking lots or adjacent } \\
\text { open space, but not physically mounted on } \\
\text { the building }\end{array}$ \\
\hline \multicolumn{3}{|c|}{ Off-Site Supply Options } \\
\hline 3 & $\begin{array}{l}\text { Use RE sources available off site to } \\
\text { generate energy on site and connected to } \\
\text { the building's electricity or hot/chilled water } \\
\text { distribution system. }\end{array}$ & $\begin{array}{l}\text { Biomass, wood pellets, ethanol, or } \\
\text { biodiesel that can be imported from off } \\
\text { site, or collected from waste streams from } \\
\text { on-site processes that can be used on site } \\
\text { to generate electricity and heat }\end{array}$ \\
\hline 4 & $\begin{array}{l}\text { Purchase recently added off-site RE } \\
\text { sources, as certified from Green-E (2009) } \\
\text { or other equivalent REC programs. } \\
\text { Continue to purchase the generation from } \\
\text { this new resource to maintain NZEB } \\
\text { status. }\end{array}$ & $\begin{array}{l}\text { Utility-based wind, PV, emissions credits, or } \\
\text { other "green" purchasing options. All off-site } \\
\text { purchases must be certified as recently } \\
\text { added RE. A building could also negotiate } \\
\text { with its power provider to install dedicated } \\
\text { wind turbines or PV panels at a site with } \\
\text { good solar or wind resources off site. In this } \\
\text { approach, the building might own the } \\
\text { hardware and receive credits for the power. } \\
\text { The power company or a contractor would } \\
\text { maintain the hardware. }\end{array}$ \\
\hline
\end{tabular}

\section{Discussion of Supply Options}

This section presents a brief discussion about the various energy supply options listed in Table 1. These options form the basis for the NZEB classification discussed later in this paper.

\section{Option 0 - Low-Energy Buildings}

Option 0 states that a building must reduce site energy use through demand-side RE and energy efficiency technologies. Option 0 is considered a prerequisite and is an essential and fundamental quality of NZEBs. A well-optimized NZEB design should include energy efficiency strategies to the point that the available RE strategies become more cost effective.

Efficiency measures or energy conversion devices such as daylighting or natural gas-fired combined heat and power devices are not considered to be on-site, supply-side RE production in 
the NZEB context. Any RE source such as passive solar space heating, solar thermal air heaters, ground-source heat pumps, and natural ventilation that cannot be commoditized, exported, and sold, are considered to be demand-side technologies and efficiency measures. Combined heat and power systems that use fossil fuels to generate heat and electricity are considered to be demand-side technologies.

\section{Option 1 - Renewable Energy Generated Within the Building Footprint}

This option covers all energy generated and used (or exported) from RE sources collected within the building footprint. Option 1 renewables apply only to a single building and to the RE connected directly into its energy distribution infrastructure. RE that is generated and used within the building footprint is directly connected to the building's electricity or hot water system, which minimizes transmission and distribution losses. This includes RE technologies mounted on the building roof or façade. Typical Option 1 technologies include PV and solar thermal systems. Building-mounted wind turbines may also have some limited application.

Building-mounted RE technologies are preferable because the collection area can be guaranteed to be available over the life of the building. Other permanent structures could include nonbuildable land and parking, and are considered in Option 2. Systems mounted within the boundary of the site, but not on the permanent building structure, could have a greater chance of being shaded, blocked, or removed because of future development needs for adjacent land.

Typically, the only area available for on-site energy production that a building has guaranteed as "its own" over its lifetime is within its footprint. To ensure this area is available for on-site production, many states, counties, and cities have solar access ordinances that declare the right to use the natural resource of solar energy as a property right. For example, the City of Boulder, Colorado, has a solar access ordinance that guarantees access to sunlight for homeowners and renters. This ordinance protects the solar access of existing buildings by limiting the amount of shadow that new development may cast on neighboring buildings, and maintains the potential for using RE systems in buildings (City of Boulder 2006). Using a PV system within the boundary of the building site to generate electricity is less favorable than a roof-mounted PV system because the area outside the building's footprint could be shaded or developed in the future. Thus, it cannot be guaranteed to provide long-term generation.

Fuel cells and microturbines that use natural gas do not generate RE and exported energy would not count toward any of these options; rather, they typically transform purchased fossil fuels into heat and electricity. This can be a valuable source-energy efficiency strategy. Energy that cannot be used by the building at the time of generation and must be exported is not counted for the purposes of defining an NZEB.

\section{Option 2 - Renewable Energy Generated Within the Boundary of the Building Site}

This option addresses RE generated on the building site but not within its footprint or mounted on the building. On-site RE is ideally connected directly to the building's electricity, hot/chilled water, or other building energy systems; however, on-site RE does not necessarily have to be directly connected if the RE equipment can be shown to be located on the building's site using a commonly accepted site definition. One example of such a building site definition (based on 40 CFR 260.10) is:

The on-site RE must be located on the property, or on property geographically contiguous to the property, on which the building is located, except that the two 
properties may be separated by an easement, public thoroughfare, transportation, or utility-owned right-of-way. Non-contiguous properties owned by the same organization but connected by a right-of-way which is controlled and to which the public does not have access, is also considered on-site property.

The site is typically defined as the property boundary; however, sites should represent a meaningful boundary that is functionally part of the building. When using this option, the site must be defined and justified.

Typical strategies include parking lot PV systems mounted to shading structures, tower-based wind turbines mounted in a neighboring field, and ground-mounted solar hot water systems connected into the building's hot water distribution system. An on-site solar-thermal absorption chiller would also be considered under this option. When available, biomass harvested from the site and used in the building (or exported) is also considered a site RE resource, as long as the resource is renewable over the life of the building.

\section{Option 3 - Off-Site Renewable Energy Used To Generate Energy On Site}

RE resources from outside the building site boundary (Options 3 and 4 in Table 1) could arguably also be used to achieve an NZEB. Often, high energy use buildings such as hospitals, laboratories, and grocery stores do not have sufficient RE generation capacity available within the building footprints or within the site boundaries. Our NZEB classification recognizes this, and was developed so all buildings could potentially reach NZEB. NZEBs that require significant off-site RE can achieve net-zero energy consumption under this classification system. However, it is not the same as a building that generates all needed energy on site and is classified as such.

Renewable sources such as wood pellets, ethanol, and biodiesel that are imported to the site can be valuable, but are less valuable than on-site renewable sources in the NZEB context. Option 3 is less preferable than Option 1 or 2 because of the energy used and the carbon footprint associated with producing and transporting the renewable resource to the building site. A building could qualify as an NZEB by using RE sources that are available off site, importing them on site, and then using them to generate energy on site. An example of this would be wood chips imported to heat a building. Other off-site renewables covered under this option include waste vegetable oil, biodiesel, and ethanol. Methane from human and animal waste treatment processes, recovery of waste energy streams from industrial processes, or landfill gas collection are all possible off-site RE generation options covered under Option 3, if they are available over the life of the building.

Biofuels from these sources can provide valuable RE with less environmental impact than fossil fuels, but are not typically considered emissions free. Understanding and documenting the life cycle emissions and carbon impacts of biofuels are important steps in including these types of renewables in NZEB project. The land needed for Option 3 renewables is also typically much greater than for Option 1 or 2.

Option 1 and 2 renewables are preferred over Option 3 renewables in the NZEB context, but Option 3 renewables are still preferred over off-site purchases of RECs (Option 4). This hierarchy values a project that takes some responsibility for generating (or using) its own RE, rather than a simple off-site REC purchase. Option 3 renewables also offer many potential 
benefits of typical distributed generation combined heat and power strategies, and significantly reduce source energy use and emissions.

\section{Option 4 - Purchase or Install Renewable Energy Generated Off Site}

This option addresses purchased RE generated off site that has been certified as a newly installed source. Typical examples include utility-based wind, RECs, and other "green" credits as certified by Green-E (2009) or other equivalent rating organizations. For a building to use this energy option and be considered an NZEB, the off-site RE generated must be a recently installed and certified RE source. This new grid-based renewable resource must also be available and purchased for the building to maintain an NZEB status.

A variation on this option could be an organization that puts into place strict efficiency goals and negotiates with its power provider to install off-site dedicated wind turbines or PV panels at a local or regional off-site location with better solar or wind resources. In this approach, the organization might finance or own the hardware (or a portion of the system) and receive credits for the power. The power company or a contractor would maintain the hardware. The building owner would probably also pay a charge to the utility to "transport" this energy. This would be a stronger commitment than buying new RECs.

A building that purchases all its RE has little incentive to reduce building loads. Through these avenues, a building could qualify as zero energy even if it directly consumes a large amount of energy generated from fossil fuels. The intentions might be good, but this type of building is the least optimal classification of an NZEB and may not reduce energy consumption overall. The NZEB classification system responds by valuing this renewable resource at the bottom of the classification.

\section{Net-Zero Energy Buildings: Definitions}

The energy performance of an NZEB can be accounted for or defined in several ways, depending on the boundary and the metric. Different definitions may be appropriate, depending on the project goals and the values of the design team and building owner. As documented and discussed by Torcellini et al. (2006), four commonly used accounting methods are net-zero site energy, net-zero source energy, net-zero energy costs, and net-zero energy emissions. Each definition uses the grid for net use accounting and has different applicable RE sources.

- Net-Zero Site Energy: A site NZEB produces at least as much RE as it uses in a year, when accounted for at the site.

- Net-Zero Source Energy: A source NZEB produces (or purchases) at least as much RE as it uses in a year, when accounted for at the source. Source energy refers to the primary energy used to extract, process, generate, and deliver the energy to the site. To calculate a building's total source energy, imported and exported energy is multiplied by the appropriate site-to-source conversion multipliers based on the utility's source energy type.

- Net-Zero Energy Costs: In a cost NZEB, the amount of money the utility pays the building owner for the RE the building exports to the grid is at least equal to the amount the owner pays the utility for the energy services and energy used over the year. 
- Net-Zero Emissions: A net-zero emissions building produces (or purchases) enough emissions-free RE to offset emissions from all energy used in the building annually. Carbon, nitrogen oxides, and sulfur oxides are common emissions that NZEBs offset. To calculate a building's total emissions, imported and exported energy is multiplied by the appropriate emission multipliers based on the utility's emissions and on-site generation emissions (if there are any).

\section{Near Zero-Energy Buildings}

A building may be designed to achieve one or more NZEB definitions, but may not achieve a net-zero energy position in operations every year. Any NZEB may fall into the near NZEB category in a given year, depending on weather, the condition of the building, operations, etc. A well-operating NZEB may also become a near NZEB during abnormal weather years that have above-average heating and cooling loads, with below-average solar and wind resources. The NZEB status should be measured, reviewed, and tracked each year with utility bills or submetering, or both.

\section{Applying a Classification System to Net-Zero Energy Buildings}

Although all attempts to achieve an NZEB are valuable, we can classify an NZEB based on the RE supply options used and definitions met. A building that offsets all its energy use from renewable resources available within the footprint is at the top of the NZEB classification system at an NZEB:A. A building that achieves an NZEB definition through a combination of on-site renenewables and off-site purchases of RECs is placed at the lowest end of the NZEB classification at an NZEB:D. Table 2 offers a method for how NZEBs can be classified based on which RE supply option the building uses. This table also summarizes how the NZEB definitions apply to the NZEB classification system.

The goal of this type of classification is to encourage building owners and designers to first use all possible cost-effective energy efficiency strategies, and then use RE sources and technologies that are located on the building. Once all possible cost-effective efficiency and on-site RE strategies have been fully exploited, off-site options should be explored if necessary. We do not wish to exclude high energy use buildings that exceed the site RE availability, and have provided for lower classified NZEBs to include all possible buildings.

The classifications are in order of preference, NZEB:A being highest, assuming other accountability and sustainability metrics are equal. For a building to achieve a certain classification, it must reach an NZEB position without needing lower classified sources. For example, consider an NZEB using site-based PV in the building's parking lot and a biomassfueled boiler, as well as some off-site RECs. If the site-based PV generates enough electricity to annually offset all energy end uses (heating, ventilation, and air-conditioning, lighting, and plug and process loads), the building would be an NZEB:B even if lower classified renewables are used. However, if site-based PV and biomass are required to offset the end uses, the building would be an NZEB:C. Finally, if site-based PV and imported biomass do not offset all energy end uses in the building, the NZEB status would depend in part on off-site credits, and the building would be an NZEB:D. 


\section{Buildings Classified as NZEB:A}

NZEB:A buildings generate and use energy through a combination of energy efficiency and RE collected within the building footprint. These buildings can qualify as site because of their use of on-site RE resources. If the source and emissions multipliers for an NZEB:A are high during times of utility energy use, but low during times the NZEB is exporting to the grid, reaching a source or emissions NZEB position may be difficult. Qualifying as a cost NZEB may be difficult, depending on the net metering policies in the area.

\section{Buildings Classified as NZEB:B}

NZEB:B buildings generate and use energy through a combination of energy efficiency, RE generated within the footprint, and RE generated within the site. These buildings can qualify as site because of their use of on-site RE resources. If the source and emissions multipliers for an NZEB:B are high during times of utility energy use, but low during times the NZEB is exporting to the grid, reaching a source or emissions NZEB position may be difficult. Qualifying as a cost NZEB may be difficult, depending on the net metering policies in the area.

\section{Buildings Classified as NZEB:C}

NZEB:C buildings use the RE strategies as described for NZEB:A and/or NZEB:B buildings to the maximum extent feasible. These buildings also use Option 3, off-site renewable resources that are brought on site to produce energy. They may qualify as site, source, and emissions NZEBs because they use renewable resources. An NZEB:C source and emission position may be difficult if carbon-neutral renewables such as wood chips are used, or if it has unfavorable source and carbon multipliers. This can occur if an NZEB exports energy when the utility has low source and carbon impacts, but imports energy when the utility has high source and carbon impacts. NZEB:C buildings typically do not reach a cost NZEB position because renewable materials are purchased to bring on site - it would be very difficult to recoup these expenses by any compensation received from the utility for RE generation.

\section{Buildings Classified as NZEB:D}

NZEB:D buildings use the energy strategies as described for NZEB:A, NZEB:B, and/or NZEB:C buildings. On-site renewable strategies are used to the maximum extent feasible. These buildings also use Option 4, purchasing certified off-site RE such as utility-scale wind and RECs from certified sources. Once all possible cost-effective efficiency and on-site RE strategies have been fully exploited, off-site options should be explored if necessary. NZEB:D buildings may qualify as source and emissions NZEBs if they purchase enough RE and have favorable source and emissions factors. They will not qualify as site and cost NZEBs. 
Table 2. Applying NZEB Definitions

\begin{tabular}{|c|c|c|c|}
\hline $\begin{array}{c}\text { NZEB } \\
\text { Classification }\end{array}$ & $\begin{array}{l}\text { Supply } \\
\text { Option } \\
\text { Number }\end{array}$ & NZEB Supply-Side Options & NZEB Definitions Met \\
\hline & 0 & $\begin{array}{l}\text { Reduce site energy use through energy efficiency and } \\
\text { demand-side renewable building technologies. }\end{array}$ & NA \\
\hline & \multicolumn{3}{|c|}{ On-Site Supply Options } \\
\hline A & 1 & $\begin{array}{l}\text { Use RE sources available within the building's footprint } \\
\text { and connected to the building's electricity or hot/chilled } \\
\text { water distribution system. } \\
\text { Reach an NZEB position without needing NZEB:B, } \\
\text { NZEB:C, or NZEB:D sources. }\end{array}$ & $\begin{array}{l}\text { YES: Site, Source, Emissions } \\
\text { Difficult: Cost } \\
\text { Potential Issues: } \\
\text { - Reaching a source or emissions NZEB position is difficult if multipliers are high } \\
\text { when utility energy is used but low when exporting to the grid. } \\
\text { - Qualifying as a cost NZEB may be difficult if net metering policies are } \\
\text { unfavorable. }\end{array}$ \\
\hline \multirow[t]{2}{*}{ B } & 2 & $\begin{array}{l}\text { NZEB:A sources may also be used } \\
\quad \text { and } \\
\text { Use RE sources that are outside the building footprint but } \\
\text { still within the building site and connected to the building's } \\
\text { electricity or hot/chilled water distribution system. } \\
\text { Reach an NZEB position without needing NZEB:C or } \\
\text { NZEB:D sources. }\end{array}$ & $\begin{array}{l}\text { YES: Site, Source, Cost, Emissions } \\
\text { Difficult: Cost } \\
\text { Potential Issues: } \\
\text { - Reaching a source or emissions NZEB position is difficult if multipliers are high } \\
\text { when utility energy is used but low when exporting to the grid. } \\
\text { - Qualifying as a cost NZEB may be difficult if net metering policies are } \\
\text { unfavorable. }\end{array}$ \\
\hline & \multicolumn{3}{|c|}{ Off-Site Supply Options } \\
\hline$C$ & 3 & $\begin{array}{l}\text { NZEB:A and/or NZEB:B sources are used (to the extent } \\
\text { feasible) } \\
\quad \text { and } \\
\text { Use RE sources available off-site to generate energy } \\
\text { through on-site processes connected to the building's } \\
\text { electricity or hot/chilled water distribution system. } \\
\text { Reach an NZEB position without needing NZEB:D sources. }\end{array}$ & $\begin{array}{l}\text { YES: Site } \\
\text { Difficult: Source, Cost, Emissions } \\
\text { Potential Issues: } \\
\text { - Reaching a source or emissions NZEB position is difficult if carbon-neutral } \\
\text { renewables are used or if source and carbon multipliers are high when utility } \\
\text { energy is used but low when exporting to the grid. } \\
\text { - Qualifying as a cost NZEB is very difficult because of the cost to purchase and } \\
\text { continually transport off-site renewable materials to the site. }\end{array}$ \\
\hline $\mathrm{D}$ & 4 & $\begin{array}{l}\text { NZEB:A and/or NZEB:B sources are used (to the extent } \\
\text { feasible), NZEB:C sources may also be used } \\
\text { and } \\
\text { Purchase recently added off-site RE sources, as certified } \\
\text { from Green-E (2009) or other equivalent REC programs. } \\
\text { Continue to purchase the generation from this new resource } \\
\text { to maintain NZEB status. }\end{array}$ & $\begin{array}{l}\text { YES: Source, Emissions } \\
\text { NO: Site, Cost } \\
\text { Potential Issues: } \\
\text { - Reaching a source and emissions NZEB position is based on the type and } \\
\text { quantity of the purchased RE. } \\
\text { - Qualifying as a site and cost NZEB is not possible. }\end{array}$ \\
\hline
\end{tabular}




\section{Off-Grid Net-Zero Energy Buildings}

Achieving an NZEB without the grid is very difficult, as the current generation of energy storage technologies is limited. Despite the electrical energy independence of off-grid buildings, they usually rely on outside energy sources such as propane and other fuels for cooking, space heating, water heating, and backup generators. Off-grid buildings cannot feed their excess energy production back onto the grid to offset other energy uses. As a result, the energy production from renewable resources must be oversized. In many cases (especially during the summer), excess generated energy cannot be used.

It is possible, though, to have a grid-independent NZEB. To do this, any backup energy needs would have to be supplied from renewable resources such as wood pellets or biodiesel. An offgrid building that uses no fossil fuels could be considered a pure NZEB, as no fossil fuels or net annual energy balances are needed or used.

\section{Zero Energy Beyond a Single Building}

As the concept of NZEBs becomes technically and economically feasible, extending its boundary to groups of buildings, campuses, communities, towns, bases, or cities becomes possible. An alternative to single NZEBs is zero-energy campuses, neighborhoods, or communities. Extending the net-zero energy boundary beyond a single building addresses the emergence of communities, neighborhoods, and campuses that generate RE for a certain group of buildings; however, the energy does not necessarily connect directly to a specific building's utility meter. This would be considered a community-based RE system that would be connected to the grid or to a district heating or cooling system.

For a large organization or a neighborhood, it is often more cost effective and efficient to generate RE in a central location on the campus or in the community, rather than on (or in addition to) each building. Community-scale systems allow for a single point for all maintenance and offer economies of scale-larger, central systems can be better optimized and cost less per kilowatt of generation capacity. Community-based RE systems, however, have some transmission and distribution losses when providing RE directly to a building. Inefficiencies and costs such as distribution piping and wiring, pumping losses, distribution transformers, and thermal losses are often associated with a district distribution system rather than with a building-based RE generation system.

The energy use accounting methods and RE supply hierarchy concepts developed in this paper for stand-alone NZEBs still apply to a community. A parallel definition system further defines zero-energy communities and extends the single-building net-zero concepts to multiple buildings with district RE systems (Carlisle et al. 2009).

\section{Conclusions}

This classification system begins ranking energy supply options in the NZEB context. As designers and owners look to design NZEBs, a discussion of which classification to achieve would be helpful in setting goals. Since the publication of the initial NZEB definition paper (Torcellini et al. 2006), we have applied these definitions to multiple NZEB examples with various RE options. This paper represents an update to the NZEB definitions based on realworld applications. Some of the buildings used to evaluate these definitions are included in the 
Zero Energy Buildings Database, which was developed by the U.S. Department of Energy and is available at www.eere.energy.gov/buildings/commercial_initiative/zero energy projects.html.

In addition to refining the definitions, we felt that it would be beneficial to classify buildings based on how well they achieve NZEB status by considering which RE supply options they use. A building that offsets all its energy use from renewable resources that are available within the footprint is at the top of the NZEB classification system at an NZEB:A. A building that achieves an NZEB definition through a combination of on-site renenewables and off-site purchases of RECs is placed at the lowest end of the NZEB classification at an NZEB:D. Figure 1 provides a simple flow chart that illustrates how to navigate the prerequisites and classification requirements to classify NZEBs.

This classification system is meant to encourage, when possible, energy efficiency strategies followed by the use of footprint and on-site RE to power buildings. The long-term benefits of these options include optimized usability of power generation capacity in the NZEB context; less reliance on and investment in the grid; less energy required because energy losses through conversion, transmission, and distribution are minimized; and fewer peak demand issues with utilities. Designers will also create more energy-efficient, high-performance buildings if the buildings must generate their own energy. The lower end of the NZEB classification also provides a means for high energy use buildings to minimize environmental impact through NZEB design strategies. This NZEB classification system is applicable to both single building projects as well as a set of buildings in a community or campus. 


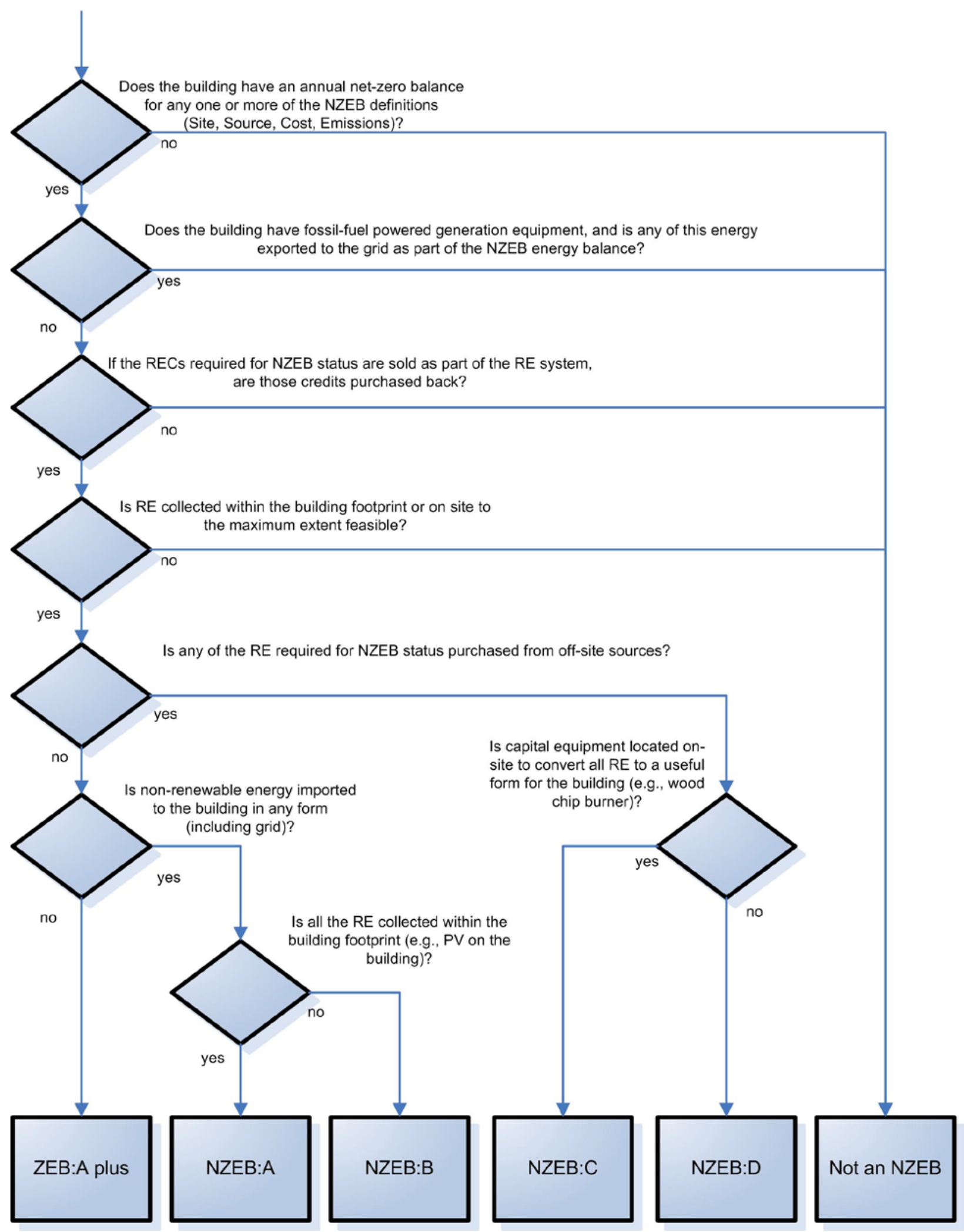

Figure 1. NZEB Classification Flow Chart 


\section{References}

Carlisle, N; VanGeet, O; Pless, S. (2009). Definition of a "Zero Net Energy" Community. NREL Report No. TP-7A2-46065. http://www.nrel.gov/docs/fy10osti/46065.pdf

City of Boulder. (2006). Solar Access Guide, Building Services Center, Boulder, Colorado http://joomla.ci.boulder.co.us/files/PDS/codes/solrshad.pdf.

Code of Federal Regulations. (2009). 40 CFR 260.10, Title 40, Protection of Environment.

Crawley, D.; Pless, S.; Torcellini, P.A. (2009). "Getting to Net Zero." ASHRAE Journal, September 2009. NREL Report No. JA-550-46382. www.nrel.gov/docs/fy09osti/46382.pdf Accessible at ASHRAE: www.ashrae.org/members/doc/1819 8003473.pdf.

Deru, M.; Torcellini, P. (2004). Improving Sustainability of Buildings through a PerformanceBased Design Approach: Preprint. NREL Report No. CP-550-36276. World Renewable Energy Congress VIII, Denver, CO: August 29-September 3, 2004. Golden, CO: National Renewable Energy Laboratory, 8 pp. www.nrel.gov/docs/fy04osti/36276.pdf.

Deru, M.; Torcellini, P. (2007). Source Energy and Emission Factors for Energy Use in Buildings (Revised). Technical Report NREL/TP-550-38617. Golden, CO: National Renewable Energy Laboratory. www.nrel.gov/docs/fy07osti/38617.pdf.

EIA. (2005). Annual Energy Review 2004. www.eia.doe.gov/emeu/aer/contents.html. Washington, DC: U.S. Department of Energy, Energy Information Administration.

Excel. (2010). Windsource. www.xcelenergy.com/Minnesota/Business/RenewableEnergy/ Windsource_Pages/Windsource.aspx. Last accessed February 2010.

Green-E. (2009). www.green-e.org/. Last accessed June 2010.

Torcellini, P.; Pless, S.; Deru, M.; Crawley, D. (2006). "Zero Energy Buildings: A Critical Look at the Definition." ACEEE Summer Study on Energy Efficiency in Buildings, August 2006, Pacific Grove, CA. Golden, CO: National Renewable Energy Laboratory, 16 pp. 


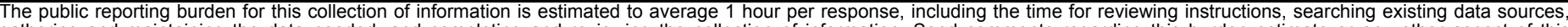

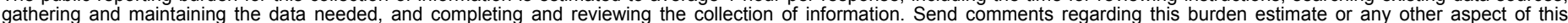

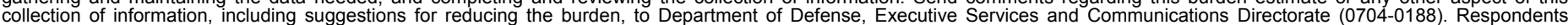

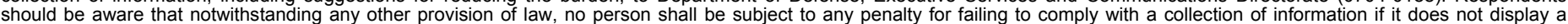

should be aware that notwithstanding

PLEASE DO NOT RETURN YOUR FORM TO THE ABOVE ORGANIZATION.

\begin{tabular}{l|l|l|l} 
1. REPORT DATE $(D D-M M-Y Y Y Y)$ & 2. REPORT TYPE & 3. DATES COVERED (FrOm - TO)
\end{tabular} June 2010

Technical Report

4. TITLE AND SUBTITLE

Net-Zero Energy Buildings: A Classification System Based on

Renewable Energy Supply Options 5a. CONTRACT NUMBER

DE-AC36-08-GO28308

5b. GRANT NUMBER

5c. PROGRAM ELEMENT NUMBER

5d. PROJECT NUMBER

NREL/TP-550-44586

5e. TASK NUMBER

BEC71123

5f. WORK UNIT NUMBER
7. PERFORMING ORGANIZATION NAME(S) AND ADDRESS(ES)

National Renewable Energy Laboratory

1617 Cole Blvd.

Golden, CO 80401-3393
8. PERFORMING ORGANIZATION REPORT NUMBER

NREL/TP-550-44586

9. SPONSORING/MONITORING AGENCY NAME(S) AND ADDRESS(ES)

10. SPONSOR/MONITOR'S ACRONYM(S)

NREL

11. SPONSORING/MONITORING AGENCY REPORT NUMBER

12. DISTRIBUTION AVAILABILITY STATEMENT

National Technical Information Service

U.S. Department of Commerce

5285 Port Royal Road

Springfield, VA 22161

13. SUPPLEMENTARY NOTES

14. ABSTRACT (Maximum 200 Words)

A net-zero energy building (NZEB) is a residential or commercial building with greatly reduced energy needs through efficiency gains such that the balance of energy needs can be supplied with renewable technologies. Past work has developed a common NZEB definition system to better the understanding of what "zero energy" means. Four welldocumented definitions-net-zero site energy, net-zero source energy, net-zero energy costs, and net-zero energy emissions - were developed. Each NZEB definition has merits as a zero energy design goal, with pluses and minuses for each. In this paper, we propose a classification system for NZEBs based on the renewable energy sources used by a building. In addition, we look at how this classification is applied to the previously developed NZEB definitions.

15. SUBJECT TERMS

zeb; zero energy building; nzeb; net zero energy building; renewable energy; classification; energy efficiency

\begin{tabular}{|c|c|c|}
\hline $\begin{array}{l}\text { a. REPORT } \\
\text { Unclassified }\end{array}$ & $\begin{array}{l}\text { b. ABSTRACT } \\
\text { Unclassified }\end{array}$ & $\begin{array}{l}\text { c. THIS PAGE } \\
\text { Unclassified }\end{array}$ \\
\hline
\end{tabular}

\begin{tabular}{|c|c|}
\hline $\begin{array}{l}\text { 17. LIMITATION } \\
\text { OF ABSTRACT }\end{array}$ & $\begin{array}{l}\text { 18. NUMBER } \\
\text { OF PAGES }\end{array}$ \\
\hline UL & \\
\hline
\end{tabular}

19a. NAME OF RESPONSIBLE PERSON

19b. TELEPHONE NUMBER (Include area code) 